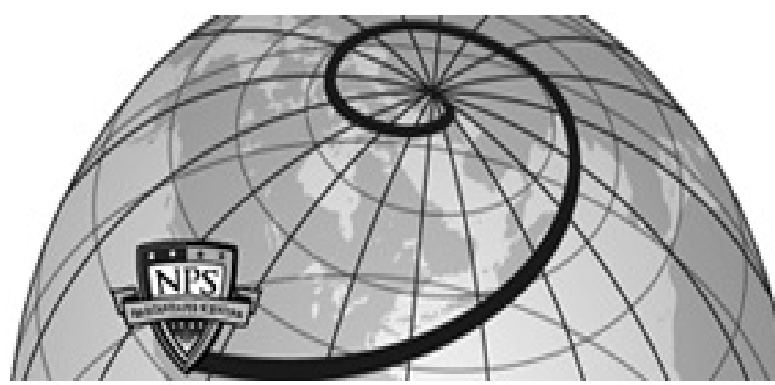

Calhoun: The NPS Institutional Archive DSpace Repository

\title{
Strategic Culture: From Clausewitz to
}

Constructivism; Strategic Insights, v. 6, issue 10 (November 2005)

\section{Lantis, Jeffrey S.}

Monterey, California. Naval Postgraduate School

Strategic Insights, v.6, issue 10 (October 2005)

https://hdl.handle.net/10945/11257

This publication is a work of the U.S. Government as defined in Title 17, United States Code, Section 101. Copyright protection is not available for this work in the United States.

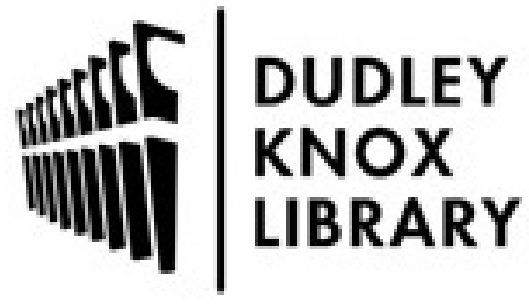

http://www.nps.edu/library
Calhoun is the Naval Postgraduate School's public access digital repository for research materials and institutional publications created by the NPS community. Calhoun is named for Professor of Mathematics Guy K. Calhoun, NPS's first appointed -- and published -- scholarly author.

Dudley Knox Library / Naval Postgraduate School 411 Dyer Road / 1 University Circle Monterey, California USA 93943 


\title{
Strategic Culture: From Clausewitz to Constructivism
}

\section{Strategic Insights, Volume IV, Issue 10 (October 2005)}

\author{
by Jeffrey S. Lantis
}

Strategic Insights is a monthly electronic journal produced by the Center for Contemporary Conflict at the Naval Postgraduate School in Monterey, California. The views expressed here are those of the author(s) and do not necessarily represent the views of NPS, the Department of Defense, or the U.S. Government.

For a PDF version of this article, click here.

\section{Introduction}

This paper charts the evolution of the theory of strategic culture through several generations of scholarship, both inside and outside the discipline, and explores contemporary arguments about the role of culture in shaping national security policy. Key questions include:

- Do cultural theories provide useful explanations of national security policy?

- Is strategic culture "semi-permanent," as most of its supporters suggest, or can it evolve over time?

- And how universal is strategic culture?

The essay concludes that while constructivism has generated new attention to ideational foundations of national security policy behavior, there remains substantial room for refinement of the research program.

Recent events have renewed scholarly interest in the role of culture in international security. Scholars and practitioners have begun to interpret challenges like the struggle to consolidate the Iraqi democracy, U.S.-China trade disputes, and the war on terror through the lens of national identity and culture. This essay charts the evolution of the theory of strategic culture through several generations of scholarly work inside and outside the discipline. Key questions include: What are the ideational foundations of national security policy? Do cultural theories, newly inspired by constructivism, provide the most accurate explanations of security policy? Is strategic culture really "semi-permanent," as its supporters suggest, or can strategic culture evolve? Who are the 'keepers' of strategic culture? And how universal is strategic culture? I conclude that while contemporary works on strategic culture offer promise, there remains substantial room for development of more reflexive models.

\section{Political Culture}

The "national character studies" of the 1940s and 1950s represented some of the first social scientific efforts to draw connections between culture and state behavior based largely on anthropological models.[1] Early work defined the roots of a nation's character, or culture, in language, religion, customs, socialization, and the interpretation of common memories.[2] While 
national character studies soon drew intense criticism, prominent sociologists and anthropologists including Mead, Douglas, and Levi-Strauss, continued to develop works linking culture and behavior.

In one of the most influential anthropological works on the subject, The Interpretation of Cultures (1973), Geertz defined culture as "an historically transmitted pattern of meanings embodied in symbols, a system of inherited conceptions expressed in symbolic form by means of which men communicate, perpetuate, and develop their knowledge about and attitudes towards life."[ㅇ] He provided a useful model of culture and suggested ways that patterns of meanings could lead to distinct behaviors.

Political scientists Almond and Verba launched a high profile study of the concept of political culture in the 1960s, defining it as "that subset of beliefs and values of a society that relate to the political system."[4] Political culture, they argued, included a commitment to values like democratic principles and institutions, ideas about morality and the use of force, the rights of individuals or collectivities, and predispositions toward the role of a country in global politics. Political culture manifests itself on at least three levels: "the cognitive, which includes empirical and causal beliefs; the evaluative, which consists of values, norms and moral judgments, and the expressive or affective, which encompasses emotional attachments, patterns of identity and loyalty, and feelings of affinity, aversion, or indifference."[్] Parsons added that culture was comprised of "interpretive codes" including language, values, and even substantive beliefs like support for democracy or the futility of war.[]

By the 1980s, interdisciplinary studies linking culture and politics had grown in popularity.[7] Sociologist Ann Swidler proposed a more complex model of connections between culture and state behavior, mediated by cultural "strategies of action." Swidler defined culture quite broadly as consisting of "symbolic vehicles of meaning, including beliefs, ritual practices, art forms, and ceremonies, as well as informal cultural practices such as language, gossip, stories, and rituals of daily life."[으 Building on the arguments of Weber and Parsons, she contended that interest-driven strategies are important, mediating conditions on state behavior.[]]

But while sociological models of culture became increasingly complex, subsequent studies of political culture yielded little theoretical refinement during this period. Critics argued that the approach was epiphenomenal and subjective, and that proponents of political culture often made exaggerated claims about its explanatory power.[10] Cultural interpretive arguments fell out of favor with the behavioral revolution in the social sciences. The concept remained alive in area studies, but it garnered less attention in mainstream international relations scholarship.

\section{Strategic Culture and National Style}

The argument that culture could influence national security policy was grounded in classic works, including the writings of Thucydides and Sun Tzu. Clausewitz advanced these ideas by recognizing war and war-fighting strategy as "a test of moral and physical forces." The goal of strategy was much more than defeat of the enemy on the battlefield-it was the elimination of the enemy's morale. Clausewitz stressed that leaders should not forget the real potential of a mobilized society, as he had witnessed first-hand in defeats by Napoleonic armies marching for the glory of the empire.[11]

In 1977, Jack Snyder brought the political cultural argument into the realm of modern security studies by developing a theory of strategic culture to interpret Soviet military strategy. Snyder suggested that elites articulate a unique strategic culture related to security-military affairs that is a wider manifestation of public opinion, socialized into a distinctive mode of strategic thinking. $\mathrm{He}$ contended, "as a result of this socialization process, a set of general beliefs, attitudes, and 
behavior patterns with regard to nuclear strategy has achieved a state of semi-permanence that places them on the level of 'cultural' rather than mere policy."[12]

Snyder applied his strategic cultural framework to interpret the development of Soviet and American nuclear doctrines as products of different organizational, historical, and political contexts and technological constraints. The result was his prediction that the Soviet military exhibited a preference for the preemptive, offensive use of force and the origins for this could be found rooted in a Russian history of insecurity and authoritarian control. Ultimately, Snyder argued that strategic culture was "semi-permanent," and new developments would be perceived only through the lens of strategic culture.

Snyder's contributions had resonance for other security policy analysts, and subsequent work on strategic culture, such as Booth's Strategy and Ethnocentrism (1979), continued to explore the ideational foundations of nuclear strategy and superpower relations. Gray (1981) also suggested that distinctive national styles, with "deep roots within a particular stream of historical experience," characterize strategy-making in countries like the United States and the Soviet Union. He defined strategic culture as "referring to modes of thought and action with respect to force, which derives from perception of the national historical experience, from aspirations for responsible behavior in national terms" and even from "the civic culture and way of life." Thus, strategic culture "provides the milieu within which strategy is debated" and serves as an independent determinate of strategic policy patterns. Like Snyder, Gray maintained that strategic culture would be a semipermanent influence on security policy.[13]

While these arguments drew attention to the role of domestic conditions in shaping national security policy behavior, critics asserted that the operationalization of strategic culture, too, was problematic and subjective. They suggested that strategic cultural models were tautological, as it would be nearly impossible to separate independent and dependent variables in a reliable way. Critics also charged that strategic cultural interpretations were by definition unique, drawing upon narrow and contextual historiography as much as anthropology. Furthermore, both supporters and detractors believed that the concept of strategic culture was fairly static, focusing on enduring historical orientations with strong predictive capability. This left little room for development of a cross-national study of the phenomenon.

Even supporters of strategic culture called for more careful study. Writing in 1988, Gray said that "social science has developed no exact methodology for identifying distinctive national cultures and styles." Literature on the "academically unfashionable subject of national character" was anecdotal at best, yet he believed that learning about the "cultural thoughtways" of a nation was crucial to understanding a country's behavior and its role in world politics.[14] Booth had called the formation of military strategy "a peculiarly ethnocentric business," and Klein argued that only a "comparative, in-depth study of the formation, influence, and process of change in the strategic cultures of the major powers in the modern era" could make a useful contribution to studies of war and peace.[15] With the abrupt end of the Cold War, strategic culture once again fell into disfavor.

\section{Strategic Culture Rediscovered: The Rise of Constructivism}

In the 1990s, a third generation of scholarly work reasserted the utility of cultural interpretations.[16] Theoretical work on strategic culture, domestic structures, and organizational culture advanced significantly in this period, influenced, in part, by the rise of constructivism. Wendt argued that state identities and interests can be seen as "socially constructed by knowledgeable practice."[17] Constructivism recognizes the importance of "inter-subjective structures that give the material world meaning," including norms, culture, identity, and ideas on state behavior or on international relations more generally.[18] Given its proclaimed ontological agnosticism, Hopf argued that the paradigm provides "a promising approach for uncovering those 
features of domestic society, culture, and politics that should matter to state identity and state action in global politics."[19]

The constructivist research program devotes particular attention to identity formation, with connections to organizational process, history, tradition, and culture. According to Hudson, constructivism "views culture as an evolving system of shared meaning that governs perceptions, communications, and actions... Culture shapes practice in both the short and long term. At the moment of action, culture provides the elements of grammar that define the situation, that reveal motives, and that set forth a strategy for success."[20] But constructivists focus primarily on social structures at the systems level, with special attention to the role of norms in international security.[21] Norms are defined as "intersubjective beliefs about the social and natural world that define actors, their situations, and the possibilities of action."[22] Tannenwald's studies of the nuclear taboo and the norm of non-proliferation, along with Legro's work on military restraint during World War II, are impressive forays into this subject, and they have generated a great deal of scholarly attention.[23]

Although the central tenets of constructivism were familiar to many-Geertz's work clearly had a significant influence on contemporary thinking, for example-Wendt and his supporters successfully framed it as a paradigmatic challenge to neorealism. One of the most controversial prongs of this challenge was the assertion by some constructivists that their approach would, assuredly, supplant neorealism as the dominant paradigm in the discipline. While this has not been accomplished, it is true that the rise of constructivism clearly energized a new wave of strategic cultural research. Farrell sees contemporary work as a merger of two relevant lines of scholarship-culturalism, as derived from comparative politics (and sociological and anthropological studies) and constructivism, from international relations theorists. Both, he contends, have recognized the impact of norms and ideas on international security. The merger of culturalism and constructivism allows us to "view actors and structure much differently than the rationalist approaches to international relations...locating actors in a social structure that both constitutes those actors and is constituted by their interactions.[24] But he does allow that differences in focus remain, with culturalists attending to social structures defined by domestic actors and conditions, and constructivists focusing on the social structure of state action in the international system.

\section{Third Generation Studies}

Johnston's Cultural Realism: Strategic Culture and Grand Strategy in Chinese History (1995) is often cited as the quintessential third generation work on strategic culture. The study set out to investigate the existence and character of Chinese strategic culture and causal linkages to the use of military force against external threats. Johnston takes the concept of strategic culture seriously as an "ideational milieu that limits behavioral choices," from which "one could derive specific predictions about strategic choice." But Johnston chose several unconventional research approaches.

He selected the intriguing period of the Ming dynasty (1368-1644) as the focus for his contemporary theoretical test. He said that strategic cultural arguments assert that "China has exhibited a tendency for the controlled, politically driven defensive and minimalist use of force that is deeply rooted in the statecraft of ancient strategists and a worldview of relatively complacent superiority."[25] Based on careful historical analysis, Johnston concluded that there were two Chinese strategic cultures in action: "one a symbolic or idealized set of assumptions and ranked preferences, and one an operational set that had a nontrivial effect on strategic choices in the Ming period."[26] Ironically, he found that while China does have characteristics of unique strategic cultures, these cultures actually exhibit some classic elements of realpolitik. 
Specialized studies of German and Japanese strategic culture also emerged in this period.[27] Berger's Cultures of Antimilitarism: National Security in Germany and Japan (1998) focused on "antimilitarist political-military cultures" to explain patterns in these countries' foreign policy behaviors.[28] Berger noted that while Japan's economic and technological power placed it in a position to become an economic and perhaps even military superpower at the end of the Cold War, the persistent postwar culture of antimilitarism truly defined Japanese security policy in the 1990s. According to Berger, cultural beliefs and values act as a distinct national lens to shape perceptions of events and even channel possible societal responses. In this sense, he states, "cultures enjoy a certain degree of autonomy and are not merely subjective reflections of concrete 'objective' reality."'[29] To Berger, antimilitarist sentiments became deeply institutionalized in Germany and Japan through a long historical process that included legitimated compromises.

Related works on German foreign policy in the 1990s interpret it as a product of both historical memory and geopolitical circumstances. Banchoff developed a consciously constructivist, "pathdependent" model of foreign policy whereby he argues that decisions taken at critical historical junctures have shaped the development of foreign policy over time. These foreign policy paths form traditions and routines which are then adopted by political institutions. "Together," he concludes, "interlocking institutions and political consensus sustained German foreign policy continuity across the 1990s divide."[30] Meanwhile, Duffield contended that political culture has significantly influenced contemporary German foreign policy within a broader international environmental context.[31] He states that far from setting off in adventurous new directions, "Germany has exercised considerable restraint and circumspection in its external relations since $1990 \ldots$... In short, notwithstanding initial fears to the contrary, Germany has acted with little more assertiveness and independent-mindedness in the area of national security than it did during the Cold War."[32] To Duffield, "[t]he overall effect of national security culture is to predispose societies in general and political elites in particular toward certain actions and policies over others. Some options will simply not be imagined...some are more likely to be rejected as inappropriate or ineffective than others."[33]

Another important strand of this scholarship focuses on military organizational cultures. For example, Kier described the significance of organizational culture in the development of French military doctrine.[34] Rosen provided a compelling account of the ways that the military and organizational cultures in India have shaped strategy over time. And in a rich work, Ebel, Taras, and Cochrane argued that the cultures of Latin American countries are distinctive, identifiable, and highly influential in the development of domestic and foreign policies.[35] According to these studies, organizational culture can be interpreted as an independent or intervening variable that directly influences strategic choice.

\section{A Research Agenda for Strategic Culture}

Generations of scholarship have produced greater understanding of ties between culture and state behavior. Strategic cultural studies have provided rich descriptions of particularistic cultures and identities, and researchers have acknowledged important links between external and internal determinants of national security policy. Cultural studies have been informed by cross-disciplinary linkages to anthropology, historical research, sociology, and psychology. Inspired by constructivism, scholars have begun to explore ways in which strategic culture is shaped and may evolve over time. As a result, even skeptics have acknowledged that contemporary works on culture offer much more than an "explanation of last resort."

But this survey of the literature also points to substantial room for refinement of the research program. Areas for further attention include the development of a common definition of strategic culture to build theoretically progressive models, delineation of the ways that strategic culture is created, maintained, and passed on to new generations, the question of the universality of strategic culture, and refinement of models of linkages between external and internal determinants of security policy. While some scholars suggest that adoption of cultural models 
represents a fundamental rejection of structure, contemporary research suggests more comprehensive models of state behavior can be developed short of falsification of the realist program.[36] Contrary to neorealist critiques of ideational frameworks, few cultural scholars believe that this really is an "either-or" theoretical debate. Furthermore, many cultural scholars recognize the need for a defined ontology as well as falsifiable, middle-range theory. In this spirit, I offer a "to-do" list for the development of new, progressive models of strategic culture in comparative perspective.

\section{Develop Common Definitions}

Given decades of scholarship on cultural determinants, one might assume that strategic culture has become an accepted independent variable in causal modeling. It has not. Snyder's definition of strategic culture as "a set of semi-permanent elite beliefs, attitudes, and behavior patterns socialized into a distinctive mode of thought" set the tone for decades of investigations.[37] Today, scholars seem to agree that distinct political cultures may exist, but definitions still blur the line between preference formation, values, and state behaviors. Pye's definition of culture as "the dynamic vessel that holds and revitalizes the collective memories of a people by giving emotional life to traditions" is a case in point.[38] Here, strategic culture becomes a generator of preferences, a vehicle for the perpetuation of values and preferences, and a force of action in revitalization and renewal of these values. Rosen said that strategic culture includes the "beliefs and assumptions that frame...choices about international military behavior, particularly those concerning decisions to go to war, preferences for offensive, expansionist or defensive modes of warfare, and levels of wartime casualties that would be acceptable."[39] While more focused on preference structures, this definition includes reference to the rules that might govern conduct in war. Delineating culture as an independent variable remains challenging, and some scholarly efforts have bordered on tautology wherein domestic political structures are identified as both reflecting and shaping political culture.[40]

Constructivism has energized work on strategic culture, but it has not advanced the search for a common definition. Hudson's contention that culture is "an evolving system of shared meaning that governs perceptions, communications, and actions..." offers little in the way of testable hypotheses.[41] And ontological agnosticism may not provide a sufficient base for theory-building in strategic cultural studies. Scholars must recognize the difficulty of drawing linkages between political structure and state behavior yet seek consensus on explanatory boundaries.[42]

Johnston offered one of the most promising avenues for a progressive research program on strategic culture by characterizing culture as "an ideational milieu which limits behavior choices." But in so doing, his efforts have drawn fire from both first generation culturalists and constructivists. Johnston frames strategic culture as "shared assumptions and decision rules that impose a degree of order on individual and group conceptions of their relationship to their social, organizational or political environment." While he noted that strategic subcultures may exist, "there is a generally dominant culture whose holders are interested in preserving the status quo." This approach to strategic culture as a set of shared assumptions and decision rules allows one to separate the strands of culture from dependent variable outcomes like strategic choice. Furthermore, Johnston's conceptual approach to strategic culture was designed to be falsifiable, "or at least distinguishable from non-strategic culture variables...[that would] provide decisionmakers with a uniquely ordered set of strategic choices from which we can derive predictions about behavior."[ 43$]$ This work is certainly informed by progress in political psychology as well as contemporary sociological studies of the complex connections between culture and state behavior.

In sum, there is real potential in the latest generation of work on strategic culture, which has tended to be more focused in its conceptualization of independent variables such as strategic cultural principles and dependent variables in specific security policy decisions. Nevertheless, there remains a significant arena for clarification of the research program. 


\section{Who are the Keepers of Strategic Culture?}

Identifying strategic culture as a set of shared assumptions and decision rules prompts the question of how they are maintained, and by whom? Most scholars prefer descriptions of political and strategic cultures as the "property of collectivities rather than simply of the individuals that constitute them."[44] For example, Wilson proposed:

"In the most general sense political cultures are socially constructed normative systems that are the product of both social (for example, rules that coordinate role relationships within the organizations) and psychological (for example, the preferences of individuals) influences but are not reducible to either...A political culture is not simply the sum of individual preferences, nor do preferences, especially those of any given individual, necessarily correspond with normative prescriptions."[늠

Acknowledging strategic culture as an "important ideational source of national predispositions, and thus of national security policy," suggests deep, but vague, cultural foundations for state behavior. If political culture is truly manifested in cognitive, evaluative, and expressive dimensions, it is conceivable that actors who carry those values might be identified. In fact, various political leaders and institutions are engaged in historical interpretation and development of the foreign policy path. This, in turn, prompts coalition-and consensus-building efforts by specific political players. To Duffield, "institutional sources of national predispositions are likely to reside in the central governmental organs charged with the formulation and execution of policy." They may shape policy by "organizational processes, routines, and standard operating procedures may constraint the types of information to which decision makers are exposed."[46] Berger suggests that political culture can only be understood as a combination of norms and political institutions which "exist in an interdependent relationship."[47]

Elites are often the purveyors of the common historical narrative.[48] Most scholars agree that elites are instrumental in defining foreign policy goals and the scope and direction of policy restructuring in the face of new challenges. Furthermore, there is a general consensus in the literature that elites are cognitively predisposed to maintain the status quo. But Berger's work on policy discourse recognizes the fact that strategic culture is best characterized as a "negotiated reality" among elites. Leaders clearly pay respect to deeply held convictions such as multilateralism and historical responsibility, but the record of past behavior for many countries also shows that leaders chose when and where to stake claims of strategic cultural traditions; they decided when and where to consciously move beyond previous boundaries of acceptability in foreign policy behavior. Ultimately, contemporary scholarship contends, elite behavior may be more consistent with the assertion that leaders are strategic "users of culture" who "redefine the limits of the possible" in key foreign and security policy discourses.[49]

Political institutions-including parties and domestic coalitions-also have a significant impact on foreign policy behavior. The organizational culture literature, for example, suggests that state behavior is a function of specific institutional orientations. Studies of Japanese and German foreign policy decisions in the 1990s argue that there are enduring institutional manifestations of strategic culture. But the keepers of the culture may not be military bureaucracies. Indeed, in Germany the Foreign Minister has dominant control over foreign and security policy. In Japan, political institutions from the Diet to the Liberal Democratic Party to the Self-Defense Forces share commitments to a foreign policy of restraint.[50] Whether or not military bureaucracies are the most common keepers of strategic culture around the world, it remains the case that the influence of organizational culture on state behavior is mediated by other institutions and by the policy making process in democratic states.

\section{Continuity or Change? The Evolution of Strategic Culture}


The focus of most studies of strategic culture is on continuity of state behavior. Eckstein (1998) suggested that the socialization of values and beliefs occurs over time. Past learning becomes sedimented in the collective consciousness and is relatively resilient to change. Lessons of the past, therefore, serve as a tight filter for any future learning that might occur.[51] An intriguing characteristic of the latest generation of cultural studies, however, is the recognition of the possibility of change over time. If historical memory, political institutions, and multilateral commitments shape strategic culture, then, recent studies argue, it would seem logical to accept that foreign policies around the globe are undergoing "enduring transformations."[52] This contribution to the strategic culture literature is informed both by studies of foreign policy restructuring and constructivist ideas on foreign policy as discourse. It also represents a response to the criticism of prior generations of cultural models as static and unresponsive to systemic pressures.[푸]

Under what conditions can strategic culture change? When might foreign policy decisions transcend the traditional bounds of strategic culture? In my own work on the subject, I contend that at least two conditions can cause "strategic cultural dilemmas" and produce changes in security policy. First, external shocks may fundamentally challenge existing beliefs and undermine past historical narratives. For German leaders in the 1990s, the scale of the humanitarian tragedies in the Balkans served as a catalyst for consideration of policy options outside the traditional bounds of German strategic culture. The recognition that groups were being systematically targeted for genocide and ethnic cleansing created a moral imperative for German action. Thus, the intensity of external shocks prompted a reexamination on all sides of the proper response. Neither economic power nor diplomacy was sufficient to prevent these tragedies, and even pacifists were forced to consider the use of military force as the final option to end the conflict. Some experts have even suggested that ethnic cleansing in Bosnia eroded the moral legitimacy of pacifism on the German political left and led to an atmosphere more permissive of the use of force to stop such violence.[54]

But most scholars rightly assert that any process of change would not be easy. Potential catalysts for change, Berger argued, might be "dramatic events or traumatic experiences [such as revolutions, wars, and economic catastrophes]," that would "discredit thoroughly core beliefs and values."[55] Such change would be accompanied by extreme psychological stress and would require a resocialization process, involving participation by various groups in the crafting of a compromise on a new political cultural orientation.[ㅎ]

Second, foreign policy behavior may break the traditional bounds of strategic cultural orientations when primary tenets of strategic thought come into direct conflict with one another. In other words, a country with interpretive codes of support for democracy and an aversion to the use of military force faces a strategic cultural dilemma when confronted by a challenge to democracy that necessitates a military response. The Japanese government confronted this question in relation to the struggle for self-determination in East Timor. The same type of dilemma may arise from a conflict between commitments to multilateralism and unilateral convictions that norms are being violated. Thompson, Ellis, and Wildavsky said that cultures remain vital only if their core principles continue to generate solutions that satisfy human needs and make sense of the world.[57] Products of this strategic cultural dissonance include occasional state defections from multilateral arrangements, the development of alternative diplomatic initiatives, or stipulations for policy cooperation.

Thus, strategic cultural dilemmas define new directions for foreign policy and demand the reconstruction of historical narratives. Changes-including abrupt and fairly dramatic reorientations of security policy behavior-appear to be possible, and strategic cultural models must be more reflective of the conditions that draw out such changes. Indeed, Swidler recognized that the relationship between state behavior and strategic culture becomes especially apparent "in unsettled cultural periods... when explicit ideologies govern action [and] structural opportunities for action determine which among competing ideologies survive in the long run." [묘] As NATO 
leaders implement a new strategic concept, China pursues liberalized trade, and the United States leads a global war on terrorism in the 21 st century, strategic cultural models must themselves adapt for long-term relevance.

Perhaps Berger is correct that strategic culture is best understood as a "negotiated reality" among foreign policy elites. While leaders clearly pay respect to deeply held convictions associated with strategic culture, the story of foreign policy development may be best understood as the pursuit of legitimation for preferred policy courses that may, or may not, conform to traditional cultural boundaries. In a recent study, Cruz contended that elites have much more latitude than scholars generally allow. They may "recast a particular agenda as most appropriate to a given collective reality or...recast reality itself by establishing a (new) credible balance between the known and the unknown." In short, Cruz argued, they "redefine the limits of the possible, both descriptively and prescriptively."[푸 $]$

\section{The Universality of Strategic Culture?}

The events of September 11th and the subsequent war on terrorism have prompted renewed attention to the role of culture in shaping state (and non-state) behaviors. But one of the most intriguing questions that carries over through several generations of scholarship is what types of actors are most likely to have defined strategic cultures. For example, Snyder made a strong case for the existence - and influence of-strategic culture in Soviet nuclear policy. Subsequent studies effectively framed U.S. and Soviet cultures within the larger Cold War context. But does the literature imply that authoritarian systems more likely to have defined strategic cultures than are democratic systems? Or, are authoritarian systems simply less likely to have definable strategic subcultures? Can non-state actors have strategic cultures? Can regional organizations or meta-cultural groups have some form of strategic culture?

A fascinating debate has emerged over whether the European Union (EU) can establish a strategic culture. The EU formalized a common European Security Strategy (ESS) for the first time in its history in December 2003. Some hailed the achievement as marking a common European strategic culture, but others question whether the EU will ever be capable of forging a bond of common threat perceptions and interests. Optimists such as Cornish and Edwards (2001) contend that "there are signs that a European strategic culture is already developing through a socialization process." They define EU strategic culture as simply "the institutional confidence and processes to manage and deploy military force as part of the accepted range of legitimate and effective policy instruments."[60] To Meyer (2004), the European Council vote on ESS in December 2003 provided a necessary "strategic concept" around which to focus attention and resources.[61] However, Lindley-French (2002) charges that Europe lacks both the capabilities and will to establish a common foreign and security policy in the foreseeable future. $\mathrm{He}$ characterizes the Europe of today as "not so much an architecture as a decaying arcade of stately structures of varying designs reflective of a bygone era."[62] Europeans disagree over threat perception and the proper responses to perceived threats, and they themselves question whether the EU can be an effective actor in the face of serious crises. Rynning (2003) concludes that the "EU is unlikely to develop a coherent and strong strategic culture" any time soon.[63]

Finally, Huntington's "civilizational thesis" pushes the envelope of theoretical interpretation.[64] He contended that states are part of broader civilizations that share strong bonds of culture, societal values, religion, and ideologies. The most important of these bonds, he argued, is religion, and "the major civilizations in human history have been closely identified with the world's great religions."[65] Meta-cultural ties, taken to the broadest level of categorization, are civilizational identities that shape modern world politics. The crux of the civilizational thesis is Huntington's argument that conflict is more likely to occur between states of different civilizations in the postCold War era.[66] Ultimately, Huntington insisted, decision-makers would be "much more likely to see threats coming from states whose societies have different cultures and hence which they do not understand and feel they cannot trust."[]] 
The civilizational thesis has drawn sharp criticism from the scholarly community. Area studies experts are critical of Huntington's willingness to propose the sweeping generalizations that were necessary to undergird the civilizational thesis. Proponents of cultural interpretations take issue with Huntington's reduction of civilizational identity to a focus on religion. They claim that this represents an over-simplification of more complex anthropological and social-psychological chords that define a cultural (or perhaps meta-cultural) group. Others have challenged Huntington's work on the obvious limitations of empirical foundation. And recent investigations of Huntington's claims (Henderson and Tucker 2001; Henderson 2000) have concluded that there is no statistically significant causal linkage before, during, or after the Cold War.[68] In the end, Huntington's work may have undermined the careful, social scientific progress that had been achieved in the cultural research program.

\section{Conclusion}

While constructivism may represent a paradigmatic challenge to structural realism in the discipline today, most supporters of strategic culture have adopted the more modest goal of "bringing culture back in" to the study of national security policy. In fact, these research traditions are more similar than some would believe. Scholars must work to overcome barriers to integration of these two approaches into a more comprehensive model of strategic culture formation, implementation, and change. Some argue that one of these barriers is a certain defensiveness on the part of neorealists, who contend that culturalists (and constructivists) simply seek to supplant neorealism.

But ultimately, even Desch allows that cultural theories might supplement neorealism by helping to explain time lags between structural change and alterations in state behavior, by accounting for seemingly "irrational" state behavior, and in helping to explain state actions in "structurally indeterminate situations."[69] For example, the cases of the evolution of German and Japanese security policies are better understood as a product of domestic political adjustments (rooted in culture, traditions, and common historical narratives) to changing international circumstances. Far from an exclusive interpretation, progressive models that explore external-internal linkages and their impact on discrete, strategic choices represent an important avenue for theoretical advancement.

Finally, constructivism has directed new attention to ideational variables and energized third generation studies. But one wonders exactly how far strategic cultural models can stretch while retaining any sort of legitimacy. For example, Basrur's study of Indian strategic culture and nuclear weapons suggests some promise, but seems to waiver on defining key actors and continuity in nuclear policy.[70] Booth and Trood's edited volume on strategic cultures in the AsiaPacific region, offers additional perspective. But by grounding their study in postpositivism, they deftly avoid the advancement of middle-range theory. Instead, they readily admit that their culturalist study is "less concerned with the immediacy and neatness of causal connections."[ $[11]$ As Checkel contends, constructivists have "succeeded in broadening the theoretical contours of international relations" by enabling research on international norms and ideas. But, he contends that a remaining ontological challenge is the need to "avoid the charge that they are reducing one unit of analysis-agents-to the other, structures (norms)."[르] Constructivists need to be very careful about the emergent "empirical ad hocism" with the invocation of "all sorts of competing implicit models of domestic politics."[그]

\section{About the Author}

Jeffrey S. Lantis is Associate Professor of Political Science and Chairperson of the Department of Political Science at The College of Wooster, Wooster, $\mathrm{OH}$. He is the original designer of the Global Problems Summit. 
For more insights into contemporary international security issues, see our Strategic Insights home page.

To have new issues of Strategic Insights delivered to your Inbox at the beginning of each month, email ccc@nps.edu with subject line "Subscribe." There is no charge, and your address will be used for no other purpose.

\section{References}

1. Two of the most prominent scholars of national character were Ruth Benedict, The Chrysanthemum and the Sword (Boston: Houghton Mifflin, 1946), and Geoffrey Gorer, The American People (New York: W.W. Norton, 1948).

2. David J. Elkins and Richard E.B. Simeon, "A Cause in Search of Its Effect, or What Does Political Culture Explain?" Comparative Politics 11, no. 2 (January 1979): 127-128.

3. See Clifford Geertz, The Interpretation of Cultures (New York: Basic Books, 1973).

4. Gabriel Almond and Sidney Verba, The Civic Culture: Political Attitudes and Democracy in Five Nations (Boston: Little, Brown, 1965), 11-14.

5. John S. Duffield, World Power Forsaken: Political Culture, International Institutions, and German Security Policy After Unification (Stanford, Calif.: Stanford University Press, 1999): 23; See also Robert D. Putnam, The Beliefs of Politicians: Ideology, Conflict, and Democracy in Britain and Italy (New Haven, Conn.: Yale University Press, 1973); Putnam, "Studying Elite Political Culture: the Case of "Ideology," American Political Science Review 65, no. 3 (September 1971): 651-681; Bert A. Rockman, Studying Elite Political Culture: Problems in Design and Interpretation (Pittsburgh, Penn.: University of Pittsburgh Press, 1976).

6. See Talcott Parsons, The Social System (Glencoe, III.: Free Press, 1951).

7. Mary Douglas and Aaron Wildavsky, Risk and Culture: An Essay on the Selection of Technical and Environmental Dangers (Berkeley: University of California Press, 1982).

8. Ann Swidler, "Culture in Action: Symbols and Strategies," American Sociological Review51, no. 2 (April 1986): 273.

9. Max Weber, The Sociology of Religion (Boston: Beacon Press, 1946a[1922-3]), 220; See also Weber, The Protestant Ethic and the Spirit of Capitalism (New York: Charles Scribner and Sons, 1958 [1904]); Related works describing the growing interest in connections between culture and political developments include: Ronald Inglehart, "The Renaissance of Political Culture," American Political Science Review82, no. 4 (1988): 1203-1230; Harry C. Triandis, Culture and Social Behavior (New York: McGraw-Hill, 1994); Aaron Wildavsky, "Choosing Preferences by Constructing Institutions: A Cultural Theory of Preference Formation," American Political Science Review81, no. 1 (1987): 3-21.

10. See Charles Lockhart, "Cultural Contributions to Explaining Institutional Form, Political Change, and Rational Decisions" Comparative Political Studies 32, no. 7 (October 1999): 862893; Lowell Dittmer, "Political Culture and Political Symbolism: Toward a Theoretical Syntheses," World Politics 29 (1977): 552-588; Ruth Lane, "Political Culture: Residual Category or General Theory?" Comparative Political Studies 25 (1992): 362-387. 
11. Michael Howard, "Clausewitz, Man of the Year," New York Times, January 28, 1991, A17.

12. Jack Snyder, The Soviet Strategic Culture: Implications for Nuclear Options, R-2154-AF (Santa Monica, Calif.: Rand Corporation, 1977), 8; See also Ken Booth, Strategy and Ethnocentrism (New York: Holmes and Meier, 1981).

13. Colin Gray, "National Style in Strategy: The American Example," International Security 6, no. 2 (Fall 1981): 35-37.

14. Colin Gray, The Geopolitics of Superpower (Lexington, Kentucky: University Press of Kentucky, 1988), 42-43.

15. Yitzhak Klein, "A Theory of Strategic Culture," Comparative Strategy 10, 1 (1991): 3; See also Richard W. Wilson, Compliance Ideologies: Rethinking Political Culture (New York: Cambridge University Press, 1992); Charles A. Kupchan, The Vulnerability of Empire (Ithaca, New York: Cornell University Press, 1994).

16. Some of the most influential works in this area for security studies include: Peter $\mathrm{J}$. Katzenstein, ed., The Culture of National Security: Norms and Identity in World Politics (New York: Columbia University Press, 1996); Alastair lain Johnston, "Thinking about Strategic Culture," International Security 19, no. 4 (Spring 1995): 32-64; Stephen Peter Rosen, "Military

Effectiveness: Why Society Matters," International Security 19, no. 4 (Spring 1995): 5-31; Elizabeth Kier, "Culture and Military Doctrine," International Security 19, no. 4 (Spring 1995): 6593; Richard J. Ellis and Michael Thompson, eds., Culture Matters: Essays in Honor of Aaron Wildavsky (Boulder, Col.: Westview Press, 1997); Yosef Lapid, "Culture's Shop: Returns and Departures in International Relations Theory," in Yosef Lapid and Friedrich Kratochwil, eds., The Return of Culture and Identity in IR Theory (Boulder, Col.: Lynne Rienner Publishers, 1996).

17. Alexander Wendt, "Anarchy is What States Make of It: The Social Construction of Power Politics," International Organization 46, no. 2 (Spring 1992): 392.

18. Peter J. Katzenstein, Robert O. Keohane, and Stephen Krasner, "International Organization and the Study of World Politics," International Organization 52, no. 4 (1998): 679.

19. Ted Hopf, "The Promise of Constructivism in International Relations," International Security 23, no.1 (Summer 1998): 914; See also Jeffrey W. Legro, "Culture and Preferences in the International cooperation Two-Step," American Political Science Review 90, no. 1 (March 1996): 118-137.

20. Valerie M. Hudson, ed. Culture and Foreign Policy (Boulder, CO: Lynne Rienner Publishers, 1997), 28-29.

21. For more detailed studies of norms in world politics, see Alexander Wendt, "Collective Identity Formation and the International State System," American Political Science Review 88, no. 2 (1994): 384-396; Martha Finnemore and Kathryn Sikkink, "International Norm Dynamics and Political Change," International Organization 52, no. 4 (1998): 887-917; Jeffrey Checkel, "Norms. Institutions and National Identity in Contemporary Europe," Arena Working Paper 98/16 (Oslo: Advanced Research on the Europeanisation of the Nation-State, University of Oslo, 1998); Ronald Jepperson, Alexander Wendt, and Peter J. Katzenstein, "Norms, Identity and Culture in National Security," in Katzenstein, ed., The Culture of National Security, 33-75.

22. Alexander Wendt, "Constructing International Politics," International Security20, no. 1 (1995): 73-74. 
23. Nina Tannenwald, "Stigmatizing the Bomb: Origins of the Nuclear Taboo," International Security 29, no. 4 (Spring 2005): 5-49; Tannenwald, "The Nuclear Taboo: The United States and the Normative Basis of Nuclear Non-Use," International Organization 53, no. 3 (Fall 1999): 83114.

24. Theo Farrell, "Constructivist Security Studies: Portrait of a Research Program," International Studies Review 4, 1 (2002), 49-72.

25. Alastair lain Johnston, Cultural Realism: Strategic Culture and Grand Strategy in Chinese History (Princeton, New Jersey: Princeton University Press, 1995), 1.

26. Johnston, Cultural Realism, x.

27. Kenneth N. Waltz, "The Emerging Structure of International Politics," International Security 18, no. 2 (Fall 1993): 71; See also Christopher Layne, "The Unipolar Illusion: Why New Great Powers will Rise," International Security 17, no. 2 (Spring 1993): 5-51.

28. Thomas U. Berger, Cultures of Antimilitarism: National Security in Germany and Japan (Baltimore, Maryland: Johns Hopkins University Press, 1998), 1; See also Berger, "From Sword to Chrysanthemum: Japan's Culture of Anti-militarism," International Security 17, no. 4 (Spring 1993): 119-150.

29. Berger, Cultures of Antimilitarism, 9.

30. Thomas Banchoff, The German Problem Transformed: Institutions, Politics, and Foreign Policy, 1945-1995 (Ann Arbor, Mich.: The University of Michigan Press, 1999), 2.

31. John S. Duffield, World Power Forsaken: Political Culture, International Institutions, and German Security Policy After Unification (Stanford, Calif.: Stanford University Press, 1999), 2; See also Duffield, "Political Culture and State Behavior: Why Germany Confounds Neorealism," International Organization 53, no. 4 (Autumn 1999): 765-803.

32. Duffield, World Power Forsaken, 4.

33. Duffield, "Political Culture and State Behavior," Op. Cit., 771.

34. Kier, "Culture and Military Doctrine: France between the Wars."

35. Roland H. Ebel, Raymond Taras, and James D. Cochran, Political Culture and Foreign Policy in Latin America: Case Studies from the Circum-Caribbean (Albany, New York: State University of New York Press, 1991).

36. Colin S. Gray, "Strategic culture as Context: The First Generation of Theory Strikes Back," Review of International Studies 25 (1999): 49-69; Keith Krause and Michael C. Williams, "Broadening the Agenda of Security Studies: Politics and Methods," Mershon International Studies Review, 40, no. 2 (October 1996): 229-254.

37. Snyder, The Soviet Strategic Culture: Implications for Nuclear Options, 8.

38. Lucian W. Pye, Asian Power and Politics: The Cultural Dimension of Authority (Cambridge, Mass: Harvard University Press, 1985), 20-22. 
39. Rosen, Societies and Military Power, 12.

40. Pye, as quoted in Lowell Dittmer, "Political Culture and Political Symbolism, Toward a Theoretical Synthesis," World Politics 29, no. 4 (July 1977): 555.

41. Hudson, Culture and Foreign Policy, 28-29.

42. See Wilson, "The Many Voices of Political Culture: Assessing Different Approaches," World Politics 52, no 2. (January 2000): 246-273.

43. Ibid., 246.

44. Duffield, World Power Forsaken, 23.

45.Wilson, "The Many Voices of Political Culture," Op. Cit., 12.

46. Duffield, World Power Forsaken, Op. Cit., 29.

47. Berger, Cultures of Antimilitarism, Op. Cit., 11-12.

48. See, for example, Sanjoy Banerjee, "The Cultural Logic of National Identity Formation: Contending Discourses in Late Colonial India," in Hudson, ed., Culture and Foreign Policy.

49. Cruz, "Identity and Persuasion," 278; For more on the strategic "use of culture" see Ann Swidler, "Culture in Action: Symbols and Strategies," American Sociological Review51 (April 1986): 273-286.

50. Duffield, World Power Forsaken, 72.

51. Harry Eckstein, "A Culturalist Theory of Political Change," American Political Science Review 82 (1998): 796.

52. Banchoff, The German Problem Transformed, 2.

53. See, for example, Charles Lockhart, "Cultural Contributions to Explaining Institutional Form, Political Change, and Rational Decisions," Comparative Political Studies 32, no. 7 (October 1999): 862-893.

54. Jeffrey S. Lantis, Strategic Dilemmas and the Evolution of German Foreign Policy Since Unification (Westport, CT: Praeger, 2002).

55. Duffield, World Power Forsaken, Op. Cit., 23.

56. Ibid., 14.

57. Michael Thompson, Richard Ellis, and Aaron Wildavsky, Cultural Theory (Boulder, Col.: Westview Press, 1990), 69-70.

58. Swidler, "Culture in Action: Symbols and Strategies," Op. Cit., 273.

59. Cruz acknowledges that this raises a critical dichotomy between culture as a system of meaning and culture as practice; Cruz, "Identity and Persuasion," Op. Cit., 278. 
60. Paul Cornish and Geoffrey Edwards, "Beyond the EU/NATO Dichotomy: the beginnings of a European strategic culture," International Affairs 77, no. 3 (2001): 587; See also Kerry Longhurst and Marcin Zaborowski, eds., Old Europe, New Europe and the Transatlantic Security Agenda (London: Routledge, 2005).

61. Christoph O. Meyer, "Theorising European Strategic Culture: Between Convergence and the Persistence of National Diversity," Centre for European Policy Studies, CEPS Working Document 204, June 2004.

62. Julian Lindley -French, "In the Shade of Locarno? Why European defence is failing," International Affairs 78, no. 4 (2002): 789; See also Steven Eberts, Lawrence Freedman, Grant Charles, Francois Heisbourg, Daniel Keohane, and Michael O'Hanlon, A European Way of War (London: Centre for European Reform, 2004); Stephan Keukeleire, "European Security and Defence Policy without an European Foreign Policy?" in Hans -Georg Erhart, ed., Die Europäische Sicherheits-und Verteidigungspolitik: Positionen, Perzeptionen, Probleme, Perspektiven (Baden-Baden: Nomos, 2002), 231-242.

63. Sten Rynning, "The European Union: Towards a Strategic Culture?" Security Dialogue 34, no. 4 (December 2003): 479.

64. Samuel P. Huntington, "The Clash of Civilizations?" Foreign Affairs 72, no. 3 (1993),: 22-49; "If Not Civilizations, What? Paradigms of the Post-Cold War World," Foreign Affairs 72, no. 5 (1993): 186-194; Samuel P. Huntington, The Clash of Civilizations and the Remaking of World Order (New York: Simon and Schuster, 1996).

65. Huntington, The Clash of Civilizations, Ibid., 47.

66. Ibid., 318.

67. Huntington, The Clash of Civilizations, 34.

68. Errol A. Henderson and Richard Tucker, "Clear and Present Strangers: The Clash of Civilizations and International Conflict," International Studies Quarterly45 (2001): 317-338; See also Errol A. Henderson, "The Democratic Peace Through the Lens of Culture, 1820-1989," International Studies Quarterly 42 (September 1998): 461-484; Henderson, "Culture or Contiguity: Ethnic Conflict, the Similarity of States, and the Onset of Interstate War, 1820-1989," Journal of Conflict Resolution 41, 649-668; Henderson, "Is the Democratic Peace an Imperialist Peace?" Paper presented at the Annual Meeting of the American Political Science Association, Washington, DC, September 2000.

69. Ibid., 166.

70. Rajesh M. Basrur, "Nuclear Weapons and Indian Strategic Culture," Journal of Peace Research, vol. 38, no.2 (March 2001): 181-198.

71. Ken Booth and Russell Trood, Strategic Cultures in the Asia-Pacific Region (New York: St. Martin's Press, 1999), 22.

72. Jeffrey T. Checkel, "The Constructivist Turn in International Relations Theory," World Politics 50, no. 2 (1998), 324.

73. Ibid., 326. 
